\title{
On the asymmetry between subject and object relative clauses in discourse context ${ }^{1}$
}

\section{Assimetria no custo de processamento de relativas de sujeito e de objeto em contextos discursivos}

\section{Renê Forster}

Universidade do Estado do Rio de Janeiro, Rio de Janeiro, Rio de Janeiro / Brasil rene.forster@gmail.com

\section{Letícia Maria Sicuro Corrêa}

Pontifícia Universidade Católica do Rio de Janeiro, Rio de Janeiro, Rio de Janeiro / Brasil 1scorrea@puc-rio.br

\begin{abstract}
This paper investigates the possibility of an effect of contextual information during the processing of sentences containing subject relative clauses (SRCs) and object relative clauses (ORCs) in Brazilian Portuguese. The predictions from one-stage models and from syntaxoriented approaches to sentence processing are outlined. An eye-tracking experiment is reported in which SRCs and ORC were presented when preceded by narrative contexts that could either favor a subject or an object relative clause analysis. The results suggest that ORCs are harder
\end{abstract}

\footnotetext{
${ }^{1}$ This paper is an extended version of the work On the unbalance between subject and object relative clauses in discourse context presented in the XXIX CUNY Conference on human sentence processing, Florida, March 3-5, 2016. This research was supported by a post-doctoral scholarship for the first author (PDJ-CNPq) and was developed in connection with the project "Processamento e aquisição da linguagem sob ótica minimalista: extensão e comparação de modelos" (PQ-CNPq) of the second author.
} 
to process when compared to SRCs, no matter what discourse contexts they are inserted in. The contextual effect obtained here can be ascribed to a pre-syntactic priming, ie. a priming effect which arises during lexical access. The possibility of pre- and post-syntactic contextual effects in the processing of RCs is discussed.

Keywords: relative clauses; sentence-processing; eye-tracking.

Resumo: Este trabalho investiga, no Português Brasileiro, a possibilidade de um efeito de informação contextual no processamento de sentenças contendo orações relativas de sujeito (RS) e de objeto (RO), considerando os possíveis impactos dessa integração para a assimetria de custo entre RSs e ROs. Previsões de modelos de base estrutural e de modelos interativos são comparadas. Um experimento de rastreamento ocular é relatado em que relativas de sujeito e de objeto foram apresentadas em contextos narrativos que favoreceriam o processamento, ou de uma relativa de sujeito, ou de uma relativa de objeto. Os resultados sugerem que ROs têm maior custo quando comparadas a relativas de sujeito, independentemente do contexto discursivo no qual estão inseridas. $\mathrm{O}$ efeito de informação contextual obtido pode ser atribuído a um efeito de priming pré-sintático, ou seja, um efeito de priming durante o acesso lexical. Discute-se a possibilidade de efeitos contextuais pré e póssintáticos no processamento de orações relativas.

Palavras-chave: orações relativas; compreensão da linguagem; rastreamento ocular.

Recebido em: 8 de janeiro de 2017.

Aprovado em: 24 de abril de 2017. 


\section{Introduction}

The asymmetry between subject relative clauses (SRCs) and object relative clauses (ORCs) has been widely reported, with higher processing costs for the latter (eg. WANNER; MARATSOS, 1978; KING; JUST, 1991; KING; KUTAS, 1995; GIBSON et al., 2005). This asymmetry has been ascribed to the transient memory load between the head of the RC (the filler) and the position in which it is recovered (the gap in the RC), in order for the processing of relativization to be accomplished (cf. (1-2)). The greater the distance between the filler and the gap, the greater the transient memory load (WANNER; MARATSOS, 1978). The need to hold the head noun in working memory as soon as the relative clause is identified and to process a subject-verb relation would account for the greater transient memory load between the filler and the gap of object RCs (CORREAA, 1986, 1995). In light of recent linguistic accounts (RIZZI, 2006, 2013), the intervention of the RC subject in ORCs would account for this asymmetry, and explain the particular difficulty of children and language impaired individuals in coping with the processing of these sentences (GRILLO, 2009; FRIEDMANN, BELLETTI; RIZZI, 2009). In any case, the structural properties of ORCs would account for the asymmetry.

(1) ... the boy that _ called the girl... (SRC)

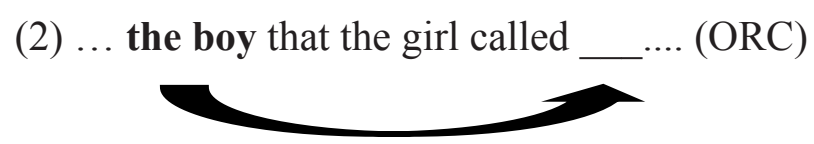

It is a point of debate, however, the extent to which the processing cost of relative clauses can be strictly attributed to their structural properties. It has been observed, for instance, that nonstructural factors such as animacy ${ }^{2}$ (MAK; VONK; SCHRIEFERS, 2002, 2006; TRAXLER; MORRIS; SEELY, 2002) and referential accessibility

\footnotetext{
${ }^{2}$ It is worth noting that if animacy is assumed to be a formal feature, animacy effects on RC processing can be accounted for by the intervention hypothesis, i.e., it can be predicted by a structural approach to language comprehension (COSTA et al., 2012).
} 
(WARREN; GIBSON, 2005) of the DPs involved in the RC can be reflected on processing costs of this type of sentences. Some results suggest further that the asymmetry between SRCs and ORCs can disappear in narrative contexts (YANG; MO; LOUWERSE, 2013).

Addressing this debate, a study using the eye-tracking methodology was conducted with restrictive ORCs (AUGUSTO; CORRÊA; FORSTER, 2012; FORSTER, 2013). An effect suggestive of the integration of previous information during the analysis of RCs was obtained, which may have some impact on the overall processing cost. In that study, there were two characters (two girls) and two background events for the processing of the test sentences. In each of the events, one of the girls was the patient of the action performed by two similar/different characters. Eye-fixations reveal that, when the previous actions were performed by different characters, the participants tended to anticipate the referent of the object of the RC, as soon as its subject (the actor of one of the previous actions) was processed, by looking immediately and longer to the correct patient (one the two girls). This effect is compatible with results suggesting the anticipation of the referent of linguistic expression in biasing contexts (ALTMANN; KAMIDE, 1999).

A similar effect was not, however, obtained in a temporarily ambiguous context, i.e. when the sentence introduced by the complementizer/ relative pronoun "that" could be preferentially interpreted as a complement sentence (FORSTER, 2013; FORSTER; CORRÊA, 2016) (cf. (3)). It seems, therefore, that a possible effect of information integration is blocked by the priority of structural factors - the minimal attachment of the embedded sentence (or the immediate satisfaction of the syntactic/ semantic requirements of the main clause verb).

(3) Mary told the girl that the painter kissed...

In Forster (2013), two explanations were proposed as a means of reconciling the on-line integration of previous information with an autonomous parser. One possibility would be that the anticipation of the patient of the event described by the $\mathrm{RC}$ would facilitate the retrieval of the head noun at the position of the gap. This retrieval would be a means of checking the prediction prompted by the identification of the subject 
of the RC (as in a sort of shadowing task ${ }^{3}$, as suggested in CORREA et al., 2012). Another possibility would be a post-syntactic priming effect (FORSTER, 2013). The background context would prime the actor-action-patient relationship presented by the RC. Once the subject of the RC was recognized, the recovery of the patient (the head noun) would be facilitated, which could, in principle, minimize possible feature interference effects. In both cases, in order for the priority of the syntactic analysis to be maintained, the immediate mapping of the subject of the $\mathrm{RC}$ onto a referent requires that DPs are processed as phases i.e. chunks of syntactically analyzed material that are transferred to the interfaces between (internal) language and processing systems (CHOMSKY, 2001) in a model of on-line computation in which sentences are analyzed from left to right (CORRÊA et al., 2012).

The present study resumes this debate by considering the extent to which a supportive context can override the asymmetry between SRCs and ORCs. An eye-tracking experiment was conducted, which was based on Yang et al.'s study (2013). Our results indicate that the asymmetry between ORCs and SRCs is unaffected by the contextual information provided.

The aim of this paper is then two-fold: to verify the extent to which the manipulation of contextual information affects the asymmetry between SRCs and ORCs and to discuss the possibilities of pre and postsyntactic contextual effects in RC processing.

This paper is organized as follows. In the next section, predictions from one-stage and from syntax-oriented models are briefly outlined. In section 3, the study conducted by Yang et al. (2013) is presented, in which the asymmetry between subject and object RCs is claimed to be neutralized.

\footnotetext{
${ }^{3}$ The shadowing technique in elicited production tasks requires the participants to repeat as quickly as possible orally presented linguistic material (isolated sentences, normal prose) as it is heard, as in simultaneous interpretation from one language to another (MARSLEN-WILSON, 1973a, b). The latency between the auditory stimulus and the onset of the repetition provides an estimate of the speed of the perception and the analysis of the linguistic material. The mean latency in the shadowing of connected speech is 250-300ms and there is evidence of anticipation (the participant produces something that has not already been heard, based on the on-going lexical/syntactic information). This type of result has been taken an indication that semantic and contextual constraints affect syntactic processing (TRUESWELL; TANNENHAUS, 1994). Alternatively, processing the material as hearer and as speaker may occur in parallel and anticipation by the speaker may be independently checked by the parser.
} 
It is argued that the interpretation of the results is not as clear as suggested, which motivates the experiment reported in section 4. In section 5, possible discourse context effects in the processing of sentences with RCs are considered, which are in tune with current developments of linguistic theory. The final remarks present some future directions of the current study.

\section{Integrating discourse information: two accounts for language comprehension}

It can be said that two main approaches to the integration of nonstructural information in sentence processing have emerged throughout the history of psycholinguistics: syntax-based approaches, giving rise to a two-stage model, and constraint-based approaches, giving rise to one stage-models. By positing an encapsulated stage for structural analysis, syntax-based accounts predict that structural factors, such as the nature of the long distance dependencies involved, are one of the main sources of processing load. According to some of those models, first pass analyses guided by syntactic information may lead to incorrect structural descriptions. In RC processing, parsing heuristics, such as the active filler strategy (CLIFTON; FRAZIER, 1989; FRAZIER; FLORES D’ARCAIS, 1989; STOWE, 1986) would create a subject-bias for relative clauses since the possibility of a subject gap would be ranked over the option of a lexically occupied subject position. This strategy leads to incorrect structural descriptions for ORCs. Reanalysis, then, would increase processing costs. Models in this tradition predict that the asymmetry between ORCs and SRCs tends to prevail irrespectively of contextual information (FRAZIER; FODOR, 1978). More recent linguistically oriented proposals ascribe this asymmetry to an overextension of a universal principle that constrains the sort of local relations that can be established in a sentence (Relativized Minimality) (RIZZI, 2006, 2013). Even though the relationship between the head of an RC and its (phonologically null) copy (in the position of the gap) is licensed in human languages, there are conditions in which intervention occurs, thereby impairing the processing of ORCs (GRILLO, 2008, 2009; FRIEDMANN; BELLETI; RIZZI, 2009; FRIEDMANN; COSTA, 2010). The effect of intervention varies as a function of the syntactic properties of the intervening element (the subject of ORCs) - the greater the similarity between its syntactic properties and those of the 
relativized element, more likely it is that intervention occurs (particularly in children and language impaired individuals who may not have access to the distinguishing WH-feature of the RC-object). In any case, insofar intervention is characterized as an interface phenomenon, the possibility of this effect being sensitive to contextual factors is an empirical question.

Approaches that rely on a general-purpose processor, with no exclusive stage for syntactic computation, claim that non structural information come into play since the very first steps of structural analysis (eg., MACDONALD; PEARLMUTTER; SEIDENBERG, 1994; TRUESWELL; TANENHAUS, 1994; STEVENSON, 1994; SPIVEY; TANENHAUS 1998; Cf. MCRAE; MATSUKI, 2012). According to one-stage models of sentence processing in constraint-based theories, initial structural descriptions can be assigned based on interpretive information, such as discourse information. Background information would then constrain the structure assigned to the currently processed material. These accounts predict that the processing cost associated with structural factors can be overridden by properties of the narrative context in which a sentence is inserted.

\section{Reading relative clauses in context: Yang et al.'s study}

The results obtained by Yang et al. (2013) in an eye-tracking experiment, are viewed as providing support for this latter account of language comprehension. In their study, the referent of the subject-DP of relative clauses was repeatedly presented in subject positions along a short narrative. The idea behind the manipulation was to create supportive contexts for either SRCs or ORCs. It seems that the rationale was the following: when reading the relative clause in a sentence like (5) after narratives like (7), readers do not fall in the trap of expecting a subject gap in the RC, since a subject function for babysitter (the proper subject of the ORC) was consistently emphasized along the story previously read. The same would hold true for sentences like (4) when read after stories like (6).

For gaze duration measures, a general facilitatory effect of contextual information was reported such that null contexts (test sentences in isolation) produced longer fixation times (see Fig. 1). This effect can be explained in terms of a purely lexical (pre-syntactic) priming mechanism that benefits from recurrent activation of a DP in previous 
discourse in line with previous observations (GRODNER et al., 2005). That is, the fact that the referents of the subject and the object of the RC are reiterated along the narrative passage can make lexical recognition and the access to the features of the lexical items easier in the analysis of the test sentences. It seems, then, that the effect of gaze duration does not say much about the attribution of structural descriptions.

In Yang et al.'s results the supportive contexts favoring SRCs led to longer reading times for ORCs when compared to SRCs, as expected. The typical asymmetry between ORCs and SRCs disappeared when the latter were read after supportive contexts intended to favor ORCs (see Fig. 1).

(4) SRC: The child that chased the babysitter squealed with delight at the game.

(5) ORC: The child that the babysitter chased squealed with delight at the game.

(6) Supportive context for SRCs: The child with a pony tail was playing on the playground with the babysitter. She looked pretty good in the pink sweater, and her white sport shoes were very cute. When the child laughed, her voice sounded sweet. On this sunny spring day, the breeze gently blew her brown hair. The child was busy picking up wildflowers, chasing the birds, and playing a game of tag.

(7) Supportive context for ORCs: The babysitter with a pony tail was playing on the playground with the child. She looked pretty good in the pink sweater, and her white sport shoes were very cute. When the babysitter laughed, her voice sounded sweet. On this sunny spring day, the breeze gently blew the brown hair. The babysitter was busy picking up wildflowers, chasing the birds, and playing a game of tag.

A closer look at Yang et al.'s data (see Fig. 1), however, calls into question the claim that the contextual information provided overrides the asymmetry between SRC and ORCS. It can be observed that ORCs are not read faster in contexts intended to favor ORCs when compared to contexts intended to favor SRCs. It seems, instead, that the processing 
of SRCs becomes relatively more difficult in contexts favoring ORCs (cf. Figure 1). It is not clear, then, whether the conclusion "the object relative clause... becomes easier to read than the subject relative clause" (YANG et al., 2013, p. 236) can be sustained.

FIGURE 1 - Results from Yang et al. (2013)

\section{Escopo Máximo}
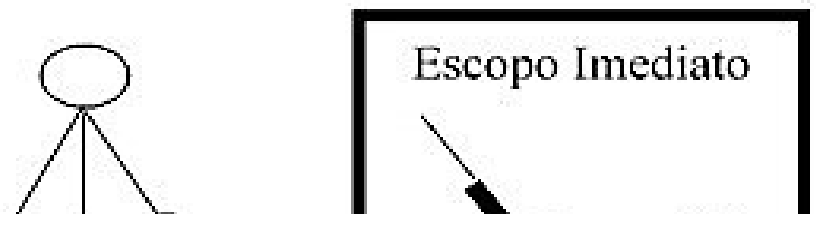

Gaze duration (left) and total fixation times (right) for relative clauses per type of narrative contexts

It is important to note that the ORC favoring condition is the only one, according to Yang at al.'s data, in which the typical asymmetry between SRCs and ORCs fails to be attested. According to the authors, this result is due to the consistent association of the referent of the $\mathrm{RC}$ subject-DP with the subject function. In the absence of the reiterated recovery of a given referent by a subject $\mathrm{RC}$ in the supportive context provided, as in Fedorenko et al. (2012), the asymmetry between ORCs and SRCs prevails. Fedorenko et al. (2012) tested relative clauses like (8) and (9) in a self-paced reading experiment. The typical asymmetry between ORCs and SRCs was observed with or without the presence of previous short narratives like (10).

(8) I heard that the reporter that attacked the senator admitted to making an error.

(9) I heard that the reporter that the senator attacked admitted to making an error 
(10) At the press-conference, a senator and two reporters got into an argument. The senator attacked one of the reporters and then the other reporter attacked the senator.

An alternative explanation for the relative difficulty of SRCs in ORC favoring context and the absence of a facilitative effect in ORCs can be provided. Given the sentence (4) in context (7), the sudden reintroduction of the DP the child after several mentions of the concurrent DP the babysitter may explain the longer reading times for SRCs in the context condition. If this is the case, it can be argued that the parsing of the embedded sentence was not necessarily affected by the contextual information provided.

\section{Experiment}

\subsection{Design and predictions}

The experiment reported here was intended to make the contrast between supportive contexts clearer than in Yang et al.'s study in order to verify the extent to which a biasing context can override the asymmetry between subject and object RCs.

As in that study, the eye-tracking methodology was used in a reading comprehension task. Unlike that study, the present one focused only on the comparison between SRCs and ORCs in two different contexts. The null condition was excluded here. The sort of experimental material used in that study was nevertheless maintained. The supportive contexts were characterized in relation to the element that is consistently presented by a DP-subject in the narrative preceding the test sentences, that is, the referent of the subject of the RC. As such, Context A was intended to favor the processing of SRC and Context B the processing of ORCs, as in Yang et al.

The reading task consisted of the silent reading of a narrative in which the critical sentence was included. A comprehension question was to be answered based on this story. The reading task and the comprehension question were followed by a distractor rating task, in which the participants should evaluate how coherent or sound the story was, using a 1 (very bad) to 5 (very good) scale, insofar as the 
experimental material, following the original study, might not sound natural in some cases. After the rating task, subjects had to press the space bar to move to the next stimulus.

The independent variables were (i) the type of $R C$ structure (SRC or ORC) ((11) \& (12)) and (ii) type of Narrative context (Context A and Context B) ((13) \& (14)), in a 2x2 factorial design. Context A emphasized the subject of SRC and Context B, the subject of ORCs.

(11) SRC: O banqueiro que [ $\Delta$ irritou o advogado] joga tênis todo sábado. The banker that irritated the lawyer plays tennis every Saturday.

(12) ORC: O banqueiro que [o advogado irritou $\Delta$ ] joga tênis todo sábado. The banker that the lawyer irritated plays tennis every Saturday.

(13) Context A - bias for SRC: O dia do banqueiro começou com uma rápida lida nos jornais para ver o que estava acontecendo no mundo. $\mathrm{O}$ telefone dele não parava de tocar. Ele atendia educadamente, mas [ele] estava esperando impacientemente a ligação do advogado. A ligação finalmente veio. $\mathbf{O}$ banqueiro falou no telefone por mais de uma hora. Apesar disso, eles não chegaram a um acordo. [RELATIVA]. Eles costumam se encontrar no clube de tênis. $\mathrm{O}$ banqueiro esperava encontrar com o advogado novamente neste sábado. (The banker's day started with a quick reading of the newspapers to see what was going on in the world. His phone didn't stop ringing. He answered politely, but [he] was impatiently waiting for a call from the lawyer. The call finally came. The banker talked on the phone for more than one hour. Despite this, they didn't come to a deal. [RELATIVE CLAUSE]. They usually meet on the tennis club. The banker hoped to meet the lawyer again this Saturday.)

(14) Context B - bias for ORC: O dia do advogado começou com uma rápida lida nos jornais para ver o que estava acontecendo no mundo. $\mathrm{O}$ telefone dele não parava de tocar. Ele atendeu educadamente, mas [ele] estava esperando impacientemente a ligação do banqueiro. A ligação finalmente veio. $\mathbf{O}$ advogado falou no telefone por mais de uma hora. Apesar disso, eles não chegaram a um acordo. [RELATIVA]. Eles 
costumam se encontrar no clube de tênis. $\mathrm{O}$ advogado esperava não ter que cruzar com o banqueiro no clube. (The lawyer's day started with a quick reading of the newspapers to see what was going on in the world. His phone didn't stop ringing. He answered politely, but [he] was impatiently waiting for a call from the banker. The call finally came. The lawyer talked on the phone for more than one hour. Despite this, they didn't come to a deal. [RELATIVE CLAUSE]. They usually meet on the tennis club. The lawyer hoped to meet the banker again this Saturday.)

Three critical regions were delimited: the head noun region (head $\mathrm{DP}+$ relative pronoun); the $\mathrm{RC}$ region (the subject-verb-object structure following the relative pronoun, in which either the subject position or the object position present a gap); and the spillover region immediately after the RC, including the main verb.

\section{(15) $\frac{\text { Head que [that] }}{1} \frac{\text { Subj. Verb Object }}{2} \frac{(. .) \text { main clause verb }}{3}$}

1. Head noun region

2. $\mathrm{RC}$ region

\section{Spill-over region}

The relevant regions for comparing the present results with the results of Yang et al. are 2 and 3. Region 1 makes it possible to capture differences in reading times due to regressions. This region was also intended to provide means of verifying if changing the referent of the main clause subject could explain the longer reading times for SRC in the ORCs supportive context in Yang et al.'s study.

The dependent variables were (i) total fixation duration at the head noun region, (ii) total fixation duration at the $\mathrm{RC}$ region, and (iii) total fixation duration at the spillover region. By total fixation duration, we mean the sum of all fixations on a portion of the sentence comprehended between the moment that the eyes first fixate on this region to the moment the last fixation in that area is detected, including all regressions. Additionally, the number of correct responses to the comprehension questions was considered. 
The following predictions were verified:

(a) If the effect of structure prevails, a main effect of RC structure is expected with longer total fixations in ORCs in the RC region and in the spillover region (the region which includes the main clause verb, where the complex subject is analyzed in relation with the verb).

(b) If the type of narrative context interferes in RC processing, in the $\mathrm{RC}$ region, an interaction between $R C$ structure and Context should be obtained, in which the asymmetry between SRC and ORC is reverted or neutralized in Context B.

\subsection{Method}

\section{PARTICIPANTS}

The participants were 41 undergraduate students (30 female) from Pontifical Catholic University of Rio de Janeiro (PUC-Rio). Nine of them were excluded due to bad calibration, errors of the researcher or due to bad performance on comprehension questions. The participants signed a term of consent and volunteered to take part in the experiment. Their participation was exchanged for course credits. The mean age of the final sample was 22.15 years old.

\section{MATERIAL}

40 test narratives were constructed, 20 for each version (favoring SRC or favoring SRC), as close as possible to the original narratives in English. There were also 40 test-sentences containing relative clauses, 20 for each version (SRCs or ORCs). Besides the critical stimuli, an additional 10 fillers and 2 training narratives were created. Four lists were constructed in such a way that the participants could see each version of a relative clause only once. Materials were presented in computer screen in a monospaced font with each $1^{\circ}$ of the visual field ranging approximately 4 characters. 


\section{APPARATUS}

A $300 \mathrm{~Hz}$ eye-tracker (with $0.5^{\circ}$ accuracy and $0.4^{\circ}$ precision) was connected to a Windows desktop computer for monitoring participants while stimuli were presented in a 23" full-hd screen. The software Tobii Studio was used for presenting stimuli, collecting data and analyzing the results. Subjects' verbal responses to comprehension questions and rating tasks were recorded through a Samson USB microphone.

\section{PROCEDURE}

Subjects had to read text passages presented at the computer screen while their eye movements were recorded. The session was preceded by a calibration phase. In this phase, subjects were required to look at 9 points in the screen. Additional recalibration points were shown in case of bad calibration. The calibration phase was followed by a training phase, in which two narratives were presented. Then, if the participant demonstrated having understood the procedure, one of the four lists of randomly ordered items was presented. After each story, question and rating task, the space bar was to be pressed for the next stimulus. The comprehension questions and rating task were orally answered by the participant. There was a break in the middle of each session in which the participant was allowed to rest. The second half of the session restarted with another calibration phase, as soon as the participant signaled to be ready. The whole session lasted between 25 and 35 minutes.

\subsection{Results}

\subsubsection{Comprehension question}

There were $91.4 \%$ correct response to the comprehension questions. The comprehension task was, therefore, easily performed. 


\subsubsection{Reading time}

The data concerning the total fixation duration $(\mathrm{ms})$ in each critical region were analyzed by means of ANOVAs. Graph 1 presents the mean total fixation duration in the head noun region in each condition. For this region, a main effect of $R C$ structure was obtained $(\mathrm{F}(1,31)=$ $13,6 \mathrm{p}>.0009)$, with longer reading times for ORCs $(\mathrm{M}=920 \mathrm{~ms})$ when compared to SRCs $(\mathrm{M}=718)$, probably due to regressions during ORC reading (cf. Graph 2).

GRAPH 1- Mean total fixation duration at the head noun region per condition (ms)

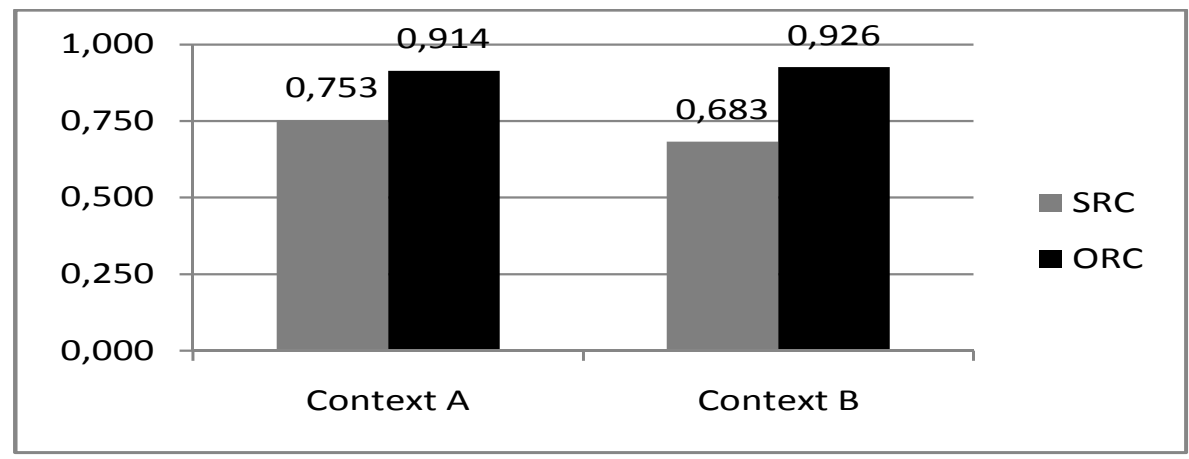

Context A: bias for subject RC | Context B: bias for object RC

GRAPH 2 - Mean total fixation duration at the head noun region per Structure of $R C(\mathrm{~ms})$

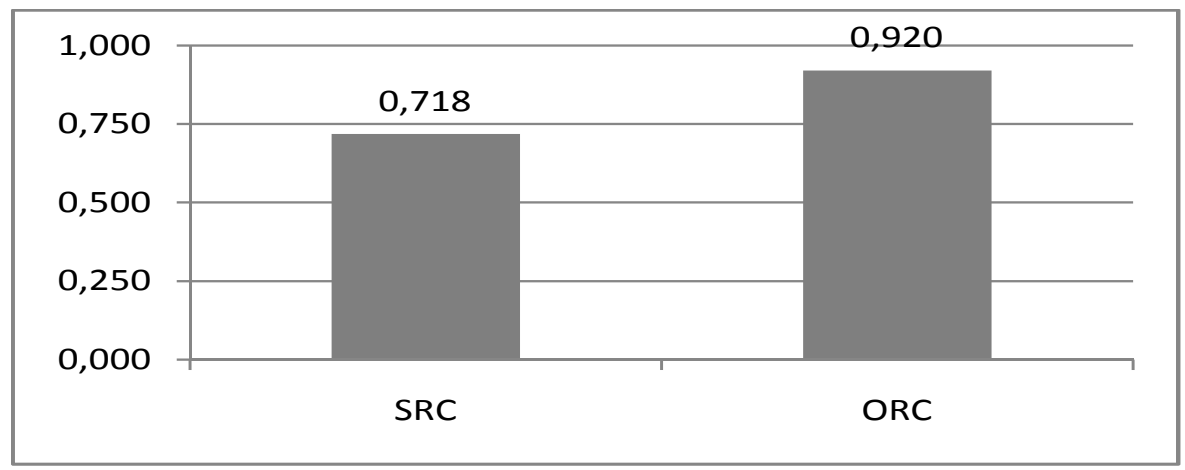


GRAPH 3 - Mean total fixation duration at the relative clause region per condition (ms)

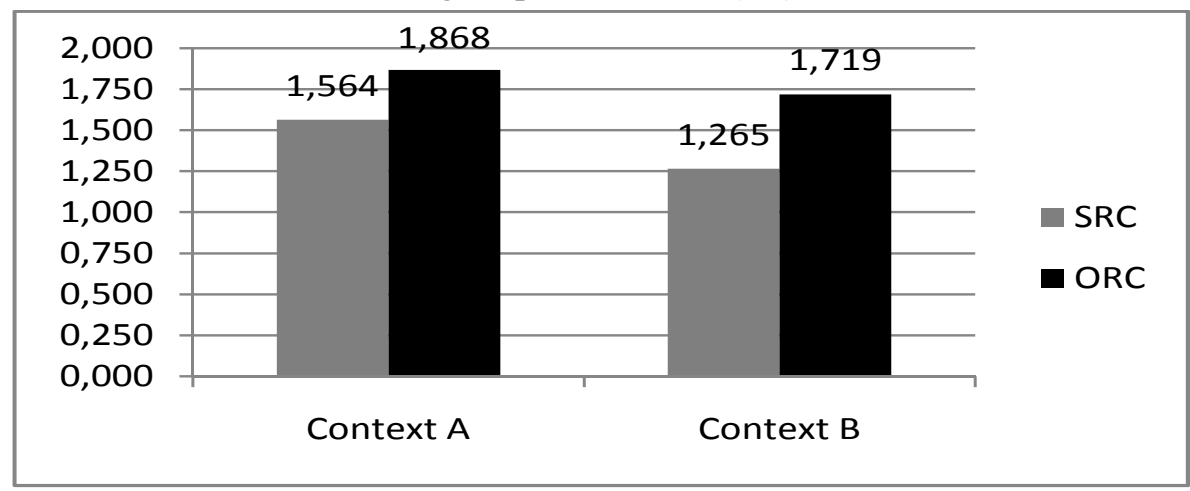

Context A: bias for subject RC | Context B: bias for object RC

For the Relative clause region, Graph 3 presents the mean total fixation duration per condition. A main effect of $R C$ structure was obtained $\left(\mathrm{F}_{1}(1,31)=24,9 \mathrm{p}<.00003 ; \mathrm{F}_{2}(1,19)=12,3 \mathrm{p}<.003\right)(\mathrm{cf}$. Graph 4). Longer reading times were associated with ORCs regardless of context. A main effect of Narrative context $\left(\mathrm{F}_{1}(1,31)=24,9 \mathrm{p}<.001\right.$; $\left.\mathrm{F}_{2}(1,19)=6,47 \mathrm{p}<.02\right)$ was also obtained, with longer reading times in context A than in B (cf. Graph 5).

GRAPH 4 - Mean total fixation duration at the relative clause region per Structure of $\mathrm{RC}(\mathrm{ms})$

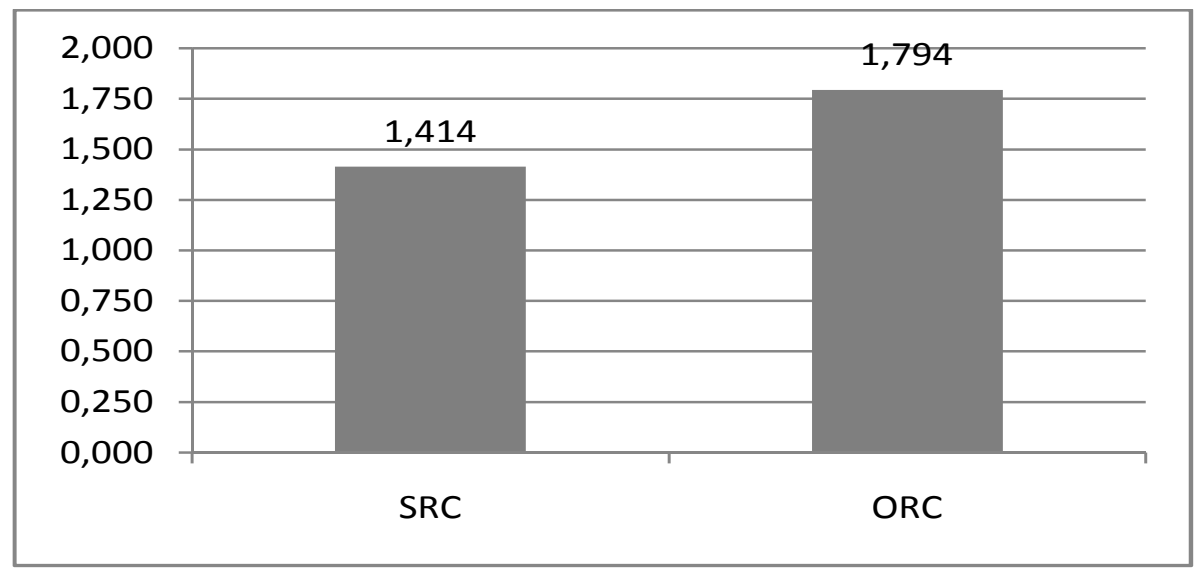


GRAPH 5 - Mean total fixation duration at the relative clause region per Context (ms)

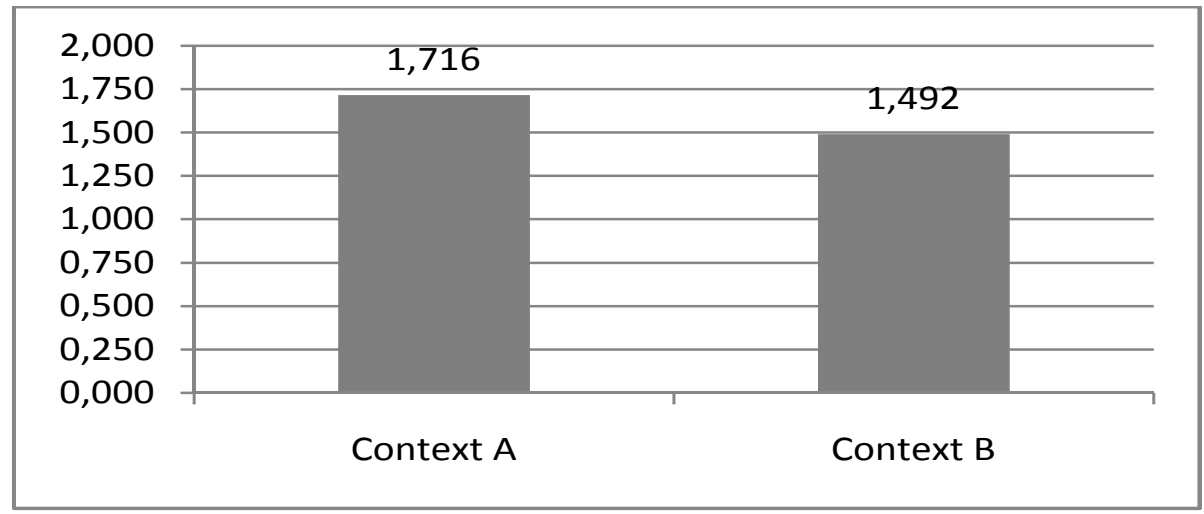

Context A: bias for subject RC | Context B: bias for object RC

Graph 6 presents the mean fixation time for the spill over region. A main effect of $R C$ structure $\left(\mathrm{F}_{1}(1,31)=35,1 \mathrm{p}<.000003 ; \mathrm{F}_{2}(1,19)\right.$ $=15,9 \mathrm{p}<.0008$ ) was obtained due to longer reading times for ORCs independently of Narrative context (cf. Graph 7). Neither a main effect of narrative context nor a significant interaction between variables was attested.

GRAPH 6 - Mean total fixation duration at the spill-over region per condition (ms)

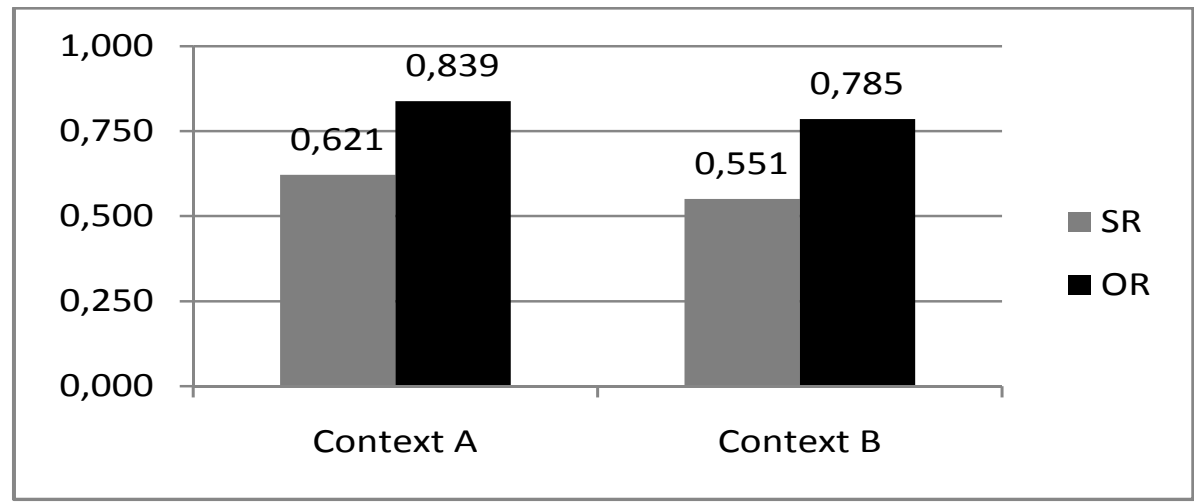

Context A: bias for subject RC | Context B: bias for object RC 
GRAPH 7 - Mean total fixation duration at the spill-over region per Structure of RC (ms)

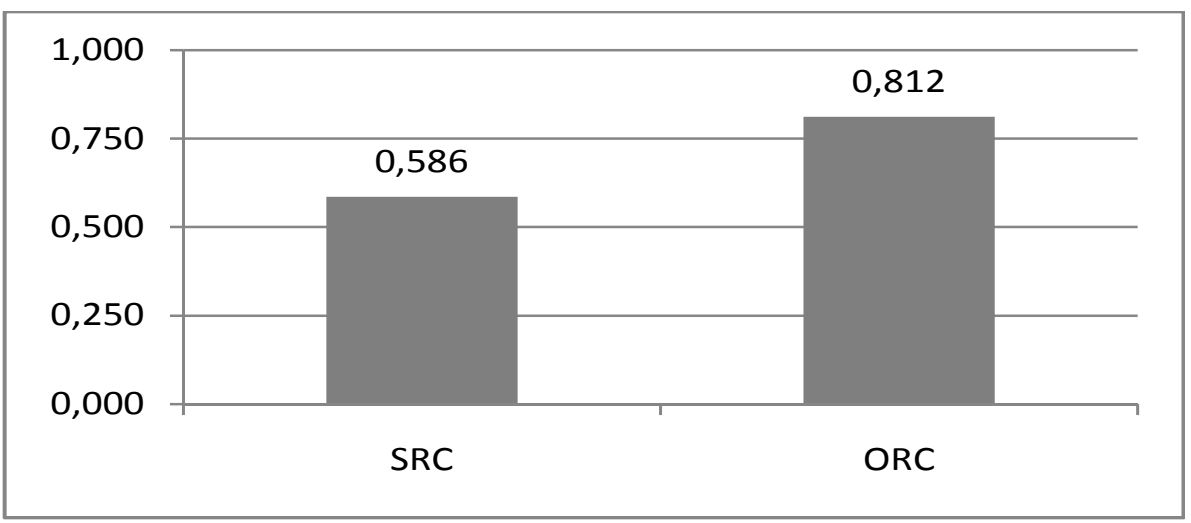

\subsection{Discussion}

The direct comparison of SRC and ORC in contexts A and B provided a clearer picture of the role of a supportive context in which the subject of the RC is reiterated as the subject of the previous sentences. The results support prediction (a): ORCs had longer total fixation duration than SRCs regardless of Context in the three critical regions. No evidence was obtained for ORC processing being facilitated by supportive contexts in such a way as to revert or neutralize the asymmetry between SRCs and ORCs (prediction (b)). Unlike Yang et al.'s results, longer times were not obtained in SRC in Context 2 in the $\mathrm{RC}$ region and no effect of context could be captured in the head noun region that could suggest that altering the referent of the subject of the main clause could have impact in the processing of SRCs. The effect of RC structure in region 1 (the head noun region) is likely to be due to regressions, since the total fixation duration includes not only first-pass reading (ie. the first time the eye passes through a word), but also backward fixations detected on a critical region. This effect seems, then, to reflect processing costs of the $\mathrm{RC}$ region and, in particular, the higher cognitive demands of ORCs. A possible effect of the alternation of the subject of the main clause in the processing of SRCs in Yang et al.'s study was not captured here. It is possible that other eye-tracking measures (related to first-pass reading) or a self-paced reading task can provide further information about the effect of the reintroduction of a possibly unexpected DP. 
Overall, these results suggest that the analysis of ORCs is more demanding than SRCs, no matter the particular context they are inserted in. Syntactic based models can explain these results as a possible feature intervention effect (GRILLO, 2008; FRIEDMANN; COSTA, 2010), which adds to the transient memory load and can lead to reanalysis (eg. CLIFTON; FRAZIER, 1989).

As for the effect of Narrative context in the RC region, it was not predicted. It does not seem to have affected the processing of the fillergap relationship per se. This effect, unlike the effect of $R C$ structure, was not maintained in the spill-over region (the matrix verb region), when the complex DP is processed as the subject of the verb. It is suggested then that the preceding context affected the processing of the critical sentence at the level of lexical access only. It seems that the repetition of the item that is overtly present in the RC in context B (advogado) (see the example (13) repeated below as (15)) has facilitated its recognition in both RC types ((16) and (17)), leading to the shorter reading times in the RCs in Context B. Facilitation is observed, then, when the DP phonetically visible inside the RC (and not the referent of the gap) is emphasized in prior discourse.

(15) Context A: O dia do advogado começou com uma rápida lida nos jornais para ver o que estava acontecendo no mundo. O telefone dele não parava de tocar. Ele atendeu educadamente, mas [ele] estava esperando impacientemente a ligação do banqueiro. A ligação finalmente veio. $\mathbf{O}$ advogado falou no telefone por mais de uma hora. Apesar disso, eles não chegaram a um acordo. [RELATIVA]. Eles costumam se encontrar no clube de tênis. $\mathrm{O}$ advogado esperava não ter que cruzar com o banqueiro no clube.

(16) SRC: O banqueiro que [ $\Delta$ irritou o advogado] joga tênis todo sábado.

(17) ORC: O banqueiro que [o advogado irritou $\Delta]$ joga tênis todo sábado.

In sum, the present data support the view that the higher processing cost of ORCs is maintained regardless of context, as suggested by Fedorenko et al. (2012). Having the two types of supportive contexts envisaged in the Yang et al.'s study contrasted, in the absence of the null 
context condition, provided a clearer assessment of the possibility of the reiterated mention of the subject of the $\mathrm{RC}$ in the subject of previous sentences alter the relative processing cost of sentences with RCs.

The more plausible explanation for the effect of context in Yang et al.'s study is that it was due to pre-syntactic lexical priming; that is, having the test sentences in a discourse context can facilitate lexical access in the RC. A spurious lexical effect along these lines may account for the main effect of context in the present study. It is also worth noting that in the narratives provided, the information conveyed by the RC was not necessarily crucial for the identification of a given referent in a set of referents of the same type. In the contexts exemplified in (6-7; 13-14), for instance, the restrictive RC singles out a single child and a single banker in the class of children and bankers, whereas in a context such as (10), the RC distinguishes a single reporter in a set of two reporters. The immediate search for the referent of the head/noun and the subject/ object of the RC, as captured in Forster et al. (2011, 2013), which may facilitated by a post-syntactic priming, is not crucially required in more descriptive RCs (as in 6-7). An effect of pre-syntactic lexical priming may therefore predominate, irrespective of the gap-filler relationship.

Given the prevalence of the effect of structure in the present results, potential contextual influence in $\mathrm{RC}$ processing can be due to either pre or post-syntactic effects. In the next section, the integration of RC information with the background context is characterized in the context of an on-line model of sentence computation, which incorporates an autonomous parser.

\section{Pre and post-syntactic effects in the on-line processing of restrictive RCs}

One of the main challenges for a syntactically oriented model of sentence processing is to account for the incremental mapping of DPs onto referents as the analysis of the sentence proceeds, which enables information from different sources to be integrated. Evidence for incrementality in sentence processing has motivated the proposal of single-stage constraint theories (eg. MACDONALD; PEARLMUTTER; SEIDENBERG, 1994; TRUESWELL; TANENHAUS, 1994; STEVENSON, 1994; SPIVEY; TANENHAUS 1998; Cf. MCRAE; MATSUKI, 2012). There is, nevertheless, compelling evidence for a syntax-first path analysis giving rise to small chunks of syntactically 
analyzed material that can be semantically interpreted and mapped onto the referential world as the analysis of the sentence proceeds (from left to right) (VOS; FRIEDERICI, 2003).

It is our contention that the current developments of (Chomskyan) generative linguistics go in the direction of minimizing the differences that have been pulling apart constraint-based theories and dual-stage models of sentence processing (cf. CORRÊA et al., 2012). Notice that universal principles that constrain possible syntactic relations in human languages are viewed as being imposed by performance systems (CHOMSKY, 1995, 2005; RIZZI, 2006, 2013) and all grammatical information is codified in the formal features of the lexical items. Formal features have interpretable and non-interpretable counterparts, which enable syntactic computation to be conducted modularly, while at the same time guaranteeing the interpretability of the product of the syntactic analysis. From a psycholinguistic point of view, having grammatical information represented as formal features of lexical items makes lexical access (which can be influenced by different factors) a precondition for syntactic processing. Moreover, computation (the merging of lexical items, giving rise to hierarchically structured objects) starts by the selection of items in an initial array or subarray. From a psycholinguistic point of view, the elements of these (sub) arrays are retrieved from the mental lexicon during on-line computation, in sentence production/ comprehension. Derivation proceeds by phase (that is, as soon as there is a chunk of semantically interpretable syntactically analyzed material, the output of syntactic computation is transferred to the interfaces levels, i.e. it becomes accessible to processing systems (CHOMSKY, 2001). These developments of linguistic theory enable a model of on-line syntactic computation to be conceived of, which can account for incrementality in sentence processing while keeping an autonomous parser (CORREA; AUGUSTO, 2007, 2011). In particular, it has been argued that having DPs as phases in an on-line model of syntactic computation, in which phases are transferred from left to right (cf. AUGUSTO; CORREA; FORSTER, 2012) makes it possible to account for pre and post-syntactic effects in the comprehension of restrictive RCs. 
FIGURE 2 - On line processing of restrictive ORC with post-syntactic priming

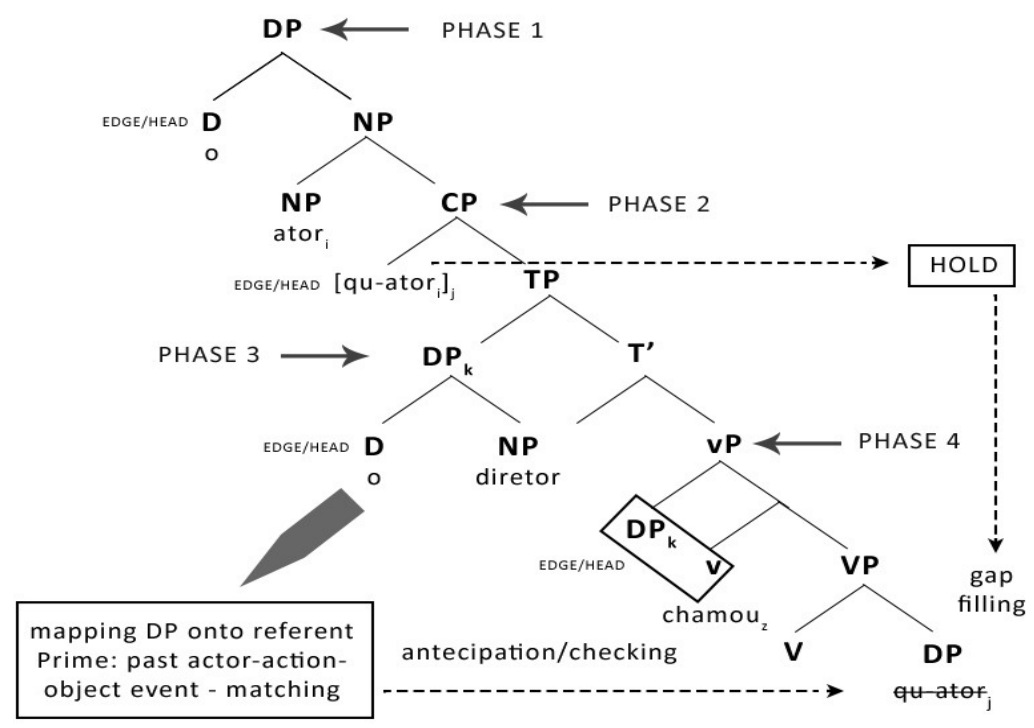

In Forster (2013), a procedural characterization of RC processing was proposed in which a post-syntactic effect of background context could be predicted. This account incorporates a processing unit equivalent to phase, and the HOLD model of RC comprehension in Corrêa (1986, 1995). According to that model, as soon as soon as the relative pronoun is recognized, the closure of the current phrase (the DP) is postponed. The head noun is held active in working memory to be retrieved when a gap is found. In the present version, the holding of the head noun would be promoted by the recognition of the relative pronoun in the edge of a phase (cf. Fig 2).

This computation presupposes recognition and access to the lexical items presented in a sequence and analyzed from left to right. Pre-syntactic effects in sentence comprehension occur in the lexical recognition process. Once lexical items are recognized (via their phonological/written form), their formal and semantic features can be retrieved from the mental lexicon. This retrieval is amenable to the effect of frequency as well as to an effect of lexical priming when sentences are processed in discourse. The frequency of the items in language use, in the previous context, their salience in previous sentence and in the 
discourse and the mere fact of having been presented can be reflected in processing speed (reading time, for instance).

Once recognized, the lexical items are merged into syntactic objects solely based on the grammatical information represented in their formal features (their semantic and phonological features are processed at the interface levels). As soon as uninterpretable features are eliminated (in the syntactic module), a chunk of information is sent to the interfaces. This syntactic object can be semantically interpreted and even mapped onto a referent/event. At the same time, its lexical features are kept active in working memory (edge features) so that further syntactic computation requiring it, such as gap filling operation, can occur. A DP mapped onto a referent (or an antecedent in discourse) may promote the retrieval of an event and its participants (introduced in the discourse by means of DPs). These DPs can then promote a post-syntactic priming effect. Keeping lexical features active in working memory makes them vulnerable to intervention effects once the analysis of the sentence proceeds (such as an immediate gap filler strategy).

Pre-syntactic effects in sentences processed in discourse contexts are expected to necessarily occur. Post-syntactic effects due to the mapping of DPs onto referents as the analysis of the sentence proceeds are likely to occur when the information in the RC is deeply integrated, that is, crucial for the identification of the referent of the head noun (as in CORRÊA et al., 2012; FORSTER, 2013).

The extent to which an effect of feature intervention can be minimized in contexts such as (10) is still an open question. There is evidence that typical and language impaired children improve their ability to process object which-questions (vulnerable to intervention) when more than one possible referent to the head noun is available in the discourse context (CORRÊA et al., 2012). In sum, pre-syntactic factors cannot affect the asymmetry between SRC and ORC, but the availability of lexical representations for syntactic computation to start. As for a postsyntactic effect, it is likely to be restricted to ORCs since the subject of a SRC can be immediately filled in as the verb is recognized. This is, nevertheless, an empirical question to be explored in the future. 


\section{Final remarks}

The present results suggest that the differential demands of SRC and ORC are maintained in narrative contexts, at least in contexts in which the referent of the subject of the $\mathrm{RC}$ is consistently presented in subject position in the preceding discourse. The higher transient memory load between the head noun and the gap in ORCs (WANNER; MARATSOS, 1978; CORREA, 1995) possibly due to feature intervention (GRILLO, 2009) is an account that can be sustained based on the present results. Previous results suggesting the neutralization of this asymmetry allow alternative interpretations. Testing the impact of the main clause subject of a sentence with a center-embedded SRC in contexts favoring ORCs, by means of a self-paced reading task, is a follow-up planned to evaluate a possible alternative explanation for the asymmetry between SRC and ORCs observed in Yang's et al. results.

The main effect of contextual information obtained in the present study seems to stem from a pre-syntactic priming effect, which is likely to affect lexical access during discourse processing. Possible postsyntactic integration of restrictive RCs with prior information require, nevertheless, further investigation. A contrast between restrictive RCs that enables the identification of a single referent in a previously introduced set of individuals of the same type with restrictive RCs that describe a distinguishing property of a previously introduced referent can provide means of verifying the extent to which integrating the subject of an ORC with a past event affects processing costs.

\section{References}

AUGUSTO, M. R. A.; CORRÊA, L. M. S.; FORSTER, R. An argument for DPs as phases in an integrated model of on-line computation: the immediate mapping of complex DPs with relative clauses. Revista Virtual de Estudos da Linguagem - ReVEL, [s.1.], v. 10, n. 6, p. 7-26, 2012.

ALTMANN, G.; KAMIDE, Y. Incremental interpretation at verbs: restricting the domain of subsequent reference. Cognition, Elsevier, v. 73, p. 247-264, 1999. https://doi.org/10.1016/S0010-0277(99)00059-1

CHOMSKY, Noam. The minimalist program. Cambridge, MA: MIT Press, 1995. 
CHOMSKY, Noam. Derivation by Phase. In: KENSTOWICZ, M. (Ed.). Ken Hale: a Life in Language. Cambridge: MIT Press, 2001. p. 1-52.

CHOMSKY, Noam. Three factors in language design. Linguistic Inquiry, MIT Press, v. 36, n. 1, p. 1-22, 2005. https://doi.org/10.1162/0024389052993655

CLIFTON JR, C.; FRAZIER, L. Comprehending sentences with longdistance dependencies. In: CARLSON, G. N.; TANENHAUS, M. K. (Ed.). Linguistic structure in language processing. Netherlands: Springer, 1989. https://doi.org/10.1007/978-94-009-2729-2_8

CORREAA, L. M. S. On the comprehension of Relative Clauses: a developmental study with reference to Portuguese. 1986. Thesis (PhD) - University of London, 1986.

CORREAA, L. M. S. The Relative Difficulty of Children's Comprehension of Relative Clauses: A Procedural Account. In: NELSON, K.; RÈGER, Z. (Org.). Children's Language. Hillsdale, N. Jersey: Lawrence Erlbaum Assoc., 1995. v. 8, p. 225-244.

CORRÊA, L. M. S.; AUGUSTO, M. R. A. Computação linguística no processamento on-line: soluções formais para a incorporação de uma derivação minimalista em modelos de processamento. Cadernos de Estudos Linguísticos, Campinas, Unicamp, v. 49, p. 167-183, 2007.

CORRÊA, L. M. S.; AUGUSTO, M. R. A. Possible loci of SLI from a both linguistic and psycholinguistic perspective. Lingua (Haarlem. Print), Elsevier, v. 121, p. 476-486, 2011.

CORRÊA, L. M. S.; AUGUSTO, M. R. A.; LONGCHAMPS, J. R.; FORSTER, R. Referência Anafórica com relativas restritivas de objeto: custo relativizado na interface gramática-pragmática. Revista LinguíStica, Rio de Janeiro, UFRJ, v. 8, n. 2, p. 173-196, 2012.

COSTA, João; GRILLO, Nino; LOBO, Maria. Minimality beyond lexical restrictions: processing and acquisition of free wh-dependencies in European Portuguese. Revue Roumaine de Linguistique, Institutul de Lingvistica al Academiei, v. 57, n. 2, p. 143-60, 2012.

FEDORENKO, E.; PIANTADOSI, S.; GIBSON, E. Processing relative clauses in supportive contexts. Cognitive Science, Wiley Online Library, v. 36, p. 471-497, 2012. 
FORSTER, R. Aspectos do processamento de orações relativas: antecipação de referentes e integração de informação contextual. 2013. Tese (Doutorado) - Pontifícia Universidade Católica do Rio de Janeiro, Rio de Janeiro, 2013. FORSTER, R.; CORRÊA, L. M. S. Rastreando o processamento de relativas de objeto: antecipação e integração de informação contextual na resolução de ambiguidades temporárias. Gragoatá, Niterói, UFF, v. 40, p. 133-156, 2016.

FRAZIER, L.; FLORES D’ARCAIS, F. G. Filler-Driven Parsing: A Study of Gap-Filling in Dutch. Journal of Memory and Language, Elsevier, v. 28, p. 331-344, 1989. https://doi.org/10.1016/0749-596X(89)90037-5

FRAZIER, L.; FODOR, J. D. The Sausage machine: A new two-stage parsing model. Cognition, Elsevier, v.6, n. 4, p. 291-235, Dec. 1978. https://doi.org/10.1016/0010-0277(78)90002-1

FRIEDMANN, N.; BELLETTI, A.; RIZZI, L. Relativized relatives: Types of intervention in the acquisition of A-bar dependencies. Lingua, Elsevier, v. 119, n. 1, p. 67-88, 2009. https://doi.org/10.1016/j.lingua.2008.09.002

FRIEDMANN, N.; COSTA, J. The child heard a coordinated sentence and wondered: On children's difficulty in understanding coordination and relative clauses with crossing dependencies. Lingua, Elsevier, v. 120, n. 6, p. 1502-1515, 2010. https://doi.org/10.1016/j.lingua.2009.10.006

GIBSON, E.; DESMET, T.; GRODNER, D.; WATSON, D.; KO, K. Reading Relative Clauses in English. Cognitive Linguistics, De Gruyter, v. 16, p. 313-53, 2005.

GORDON, P. C, R. HENDRICK, M. JOHNSON. Effects of noun phrase type on sentence complexity. Journal of Memory and Language, Elsevier, v. 51, p. 97-114, 2004. https://doi.org/10.1016/j.jml.2004.02.003

GRILLO, N. Generalized minimality: syntactic underspecification in Broca's aphasia. 2008. Dissertation (PhD.) - University of Utrecht, 2008. https://doi.org/10.1016/j.lingua.2008.04.003

GRILLO, N. Generalized Minimality: Feature impoverishment and comprehension deficits in agrammatism. Lingua, Elsevier, v. 119, n. 10, p. 1426-1443, 2009. 
GRODNER, D.; GIBSON, E.; WATSON, D. The influence of contextual contrast on syntactic processing: Evidence for strong-interaction in sentence comprehension. Cognition, Elsevier, v. 95, p. 275-296, 2005. https://doi.org/10.1016/j.cognition.2004.01.007

KING, J.; JUST, M. Individual differences in syntactic processing: the role of working memory. Journal of Memory and Language, Elsevier, v. 30, p. 580-602, 1991. https://doi.org/10.1016/0749-596X(91)90027-H

KING, J.; W.; KUTAS, M. Who Did What and When? Using Word- and Clause-Level ERPs to Monitor Working Memory Usage in Reading. Journal of Cognitive Neuroscience, MIT Press, v. 7, p. 376-95, 1995. https://doi.org/10.1162/jocn.1995.7.3.376

MACDONALD, M. C.; PEARLMUTTER, N. J.; SEIDENBERG, M. $\mathrm{S}$. The lexical nature of syntactic ambiguity resolution. Psychological Review, Elsevier, v. 101, n. 4, p. 676-703, Oct. 1994. https://doi. org/10.1037/0033-295X.101.4.676

MAK, W. M.; VONK, W.; SCHRIEFERS, H. The Influence of Animacy on Relative Clause Processing. Journal of Memory and Language, Elsevier, v. 47, p. 50-68, 2002. https://doi.org/10.1006/jmla.2001.2837

MAK, W. M.; VONK, W.; SCHRIEFERS, H. Animacy in processing relative clauses: The hikers that rocks crush. Journal of Memory and Language, Elsevier, v. 54, p. 466-490, 2006. https://doi.org/10.1016/j. jml.2006.01.001

MARSLEN-WILSON, W. D. Linguistic structure and speech shadowing at very short latencies. Nature, Springer Nature, v. 244, p. 522-523, 1973. https://doi.org/10.1038/244522a0

MARSLEN-WILSON, W.D. Speech shadowing and speech comprehension. Speech Communication, Elsevier, n. 4, n.1-3, p. 55-73, 1985. https://doi. org/10.1016/0167-6393(85)90036-6

MCRAE, K.; MATSUKI, K. Constraint-based Models of Sentence Processing. In: VAN GOMPEL, R. (Ed.). Sentence Processing. New York: Psychology Press, 2012.

RIZZI, L. Relativized Minimality. Cambridge Mass.: MIT Press, 1990.

RIZZI, L. On the form of chains: Criterial positions and ECP effects. Current Studies in Linguistics Series, MIT Press, v. 42, p. 97, 2006. 
RIZZI, L. Locality. Lingua, Elsevier, v. 130, p. 169-186, 2013.

SPIVEY, M. J.; TANENHAUS, M. K. Syntactic ambiguity resolution in discourse: Modeling the effects of referential context and lexical frequency. Journal of Experimental Psychology: Learning, Memory and Cognition, Washington, v. 24, p. 1521-1543, 1998.

STEVENSON, S. Competition and recency in a hybrid network model of syntactic disambiguation. Journal of Psycholinguistic Research, Springer Link, v. 23, p. 295-322, 1994.

STOWE, L. A. Parsing WH-constructions: Evidence for online gap location. Language and Cognitive Processes, Taylor \& Francis Online, n.1, p. 227-245, 1986.

TRAXLER, M. J.; MORRIS, R. K.; SEELY, R. E. Processing subject and object relative clauses: Evidence from eye movement. Journal of Memory and Language, Elsevier, v. 47, p. 69-90, 2002. https://doi.org/10.1006/ jmla.2001.2836

TRUESWELL, J. C.; TANENHAUS, M. K. Toward a lexicalist framework for constraint-based syntactic ambiguity resolution. In: CLIFTON; FRAZIER; RAYNER (Ed.). Perspectives on Sentence Processing. Hillsdale, NJ: LEA Press, 1994. p. 155-179.

VOS, S. H.; FRIEDERICI, A. D. Intersentential syntactic context effects on comprehension: The role of working memory. Cognitive Brain Research, Bethesda, v. 16, n. 1, p. 111-122, 2003. https://doi.org/10.1016/ S0926-6410(02)00226-4

WANNER, E.; MARATSOS, M. An ATN approach to comprehension. In: HALLE, M. BRESNAN, J.; MILLER, G. A. (Ed.). Linguistic Theory and Psychological Reality. Massachusetts: MIT Press, 1978.

WARREN, T.; GIBSON, E. Effects of NP type in reading cleft sentences in English. Language and Cognitive Processes, Taylor \& Francis Online, v. 20, p. 751-767, 2005.

YANG, F.; MO, L.; LOUWERSE, M. M. Effects of local and global context on processing sentences with subject and object relative clauses. Journal of Psycholinguistic Research, Springer Link, v 42, n. 3, p. 227-237, 2013. 


\section{APPENDIX A}

(1)

[SRC] O banqueiro que irritou o advogado joga tênis todo sábado.

[ORC] O banqueiro que o advogado irritou joga tênis todo sábado.

(2)

[SRC] A criança que achou a babá ria alegremente da brincadeira.

[ORC] A criança que a babá achou ria alegremente da brincadeira.

(3)

[SRC] O piloto que elogiou a aeromoça a chamou para um encontro.

[ORC] O piloto que a aeromoça elogiou a chamou para um encontro.

(4)

[SRC] O atacante que odiava o zagueiro agrediu o rival.

[ORC] $\mathrm{O}$ atacante que o zagueiro odiava agrediu o rival.

(5)

[SRC] O executivo que amava a secretária chamou até o porteiro para festa.

[ORC] $\mathrm{O}$ executivo que a secretária amava chamou até o porteiro para festa.

(6)

[SRC] O médico que ignorava a enfermeira dirigia um conversível vermelho.

[ORC] $\mathrm{O}$ médico que a enfermeira ignorava dirigia um conversível vermelho.

(7)

[SRC] O mecânico que namorava a garçonete sempre a convidava para almoçar.

[ORC] O mecânico que a garçonete namorava sempre a convidava para almoçar.

(8)

[SRC] A escritora que elogiou o fotógrafo trabalhava para uma revista de arte.

[ORC] A escritora que o fotógrafo elogiou trabalhava para uma revista de arte.

(9)

[SRC] O ladrão que assustou o policial já tinha assaltado três casas naquela semana.

[ORC] O ladrão que o policial assustou já tinha assaltado três casas naquela semana.

(10)

[SRC] a editora que aborreceu a escritora demitiu toda a equipe.

[ORC] a editora que a escritora aborreceu demitiu toda a equipe.

(11)

[SRC] O prisioneiro que atacou o carcereiro provocou a rebelião.

[ORC] O prisioneiro que o carcereiro atacou provocou a rebelião. 
(12)

[SRC] O coreógrafo que admirava a dançarina deu a ela o papel principal.

[ORC] O coreógrafo que a dançarina admirava deu a ela o papel principal.

[SRC] A lavradora que desprezava o fazendeiro ligou para os jornais e reclamou.

[ORC] A lavradora que o fazendeiro desprezava ligou para os jornais e reclamou.

[SRC] A professora que criticou o estudante ficou um pouco envergonhada.

[ORC] A professora que o estudante criticou ficou um pouco envergonhada.

(15)

[SRC] A cliente que desagradou o psicólogo não voltou mais às sessões.

[ORC] A cliente que o psicólogo desagradou não voltou mais às sessões.

[SRC] O jogador que gostava do carregador foi chamado para um torneio profissional.

[ORC] O jogador que o carregador gostava foi chamado para um torneiro profissional.

[SRC] O caçador que viu o guarda saiu correndo pela floresta.

[ORC] O caçador que o guarda viu saiu correndo pela floresta.

[SRC] O historiador que criticou o estudante se sentiu mal por aquela situação.

[ORC] O historiador que o estudante criticou se sentiu mal por aquela situação.

(19)

[SRC] A atriz que convocou o diretor pediu o papel principal do novo filme.

[ORC] A atriz que o diretor convocou pediu o papel principal no novo filme.

(20)

[SRC] O lobo que atacou a serpente feriu gravemente o animal.

[ORC] O lobo que a serpente atacou feriu gravemente o animal. 